\begin{tabular}{|l|l|l|}
\hline \multicolumn{2}{|c|}{ PublisherInfo } \\
\hline \hline PublisherName & $:$ & BioMed Central \\
\hline \hline PublisherLocation & $:$ & London \\
\hline \hline PublisherImprintName & $:$ & BioMed Central \\
\hline \hline
\end{tabular}

\title{
Induced Hypothermia post Cardiac Arrest
}

\begin{tabular}{||l|l|l||}
\hline \multicolumn{3}{|c||}{ ArticleInfo } \\
\hline \hline ArticleID & $:$ & 4328 \\
\hline \hline ArticleDOI & $:$ & $10.1186 /$ ccf-2002-76651 \\
\hline \hline ArticleCitationID & $:$ & 76651 \\
\hline \hline ArticleSequenceNumber & $:$ & 28 \\
\hline \hline ArticleCategory & $:$ & Paper Report \\
\hline \hline ArticleFirstPage & $:$ & 1 \\
\hline \hline ArticleLastPage & $:$ & 3 \\
\hline \hline & & RegistrationDate $: 2002-3-21$ \\
ArticleHistory & $:$ & Received \\
& Accepted 2002-3-21 & $:$ 2002-4-4 \\
& & OnlineDate $\quad$ 2002-4-8 \\
\hline \hline ArticleCopyright & $:$ & Biomed Central Ltd2002 \\
\hline \hline ArticleGrants & $:$ & \\
\hline \hline
\end{tabular}




\begin{tabular}{|l|l|l|}
\hline ArticleContext & $:$ & 1305466 \\
\hline
\end{tabular}

Michael DePietro, ${ }^{\text {Aff1 }}$

Aff1 Christiana Hospital, Delaware, USA

\section{Keywords}

hypothermia, cardiac arrest, hypoxic-ischemia injury

\section{Context}

This study was published in the same issue of The NEJM as the similar study by The Hypothermia After Cardiac Arrest Study Group. Like the Study Group investigators, Bernard et al point out that induced hypothermia has been shown to exert cerebral protective effects during and after cardiac arrest, both in animal models and uncontrolled human trials. The authors conducted a randomized human trial of induced hypothermia following successfully resucitated cardiac arrest.

\section{Significant findings}

The authors studied 77 patients who sustained a cardiac arrest secondary to ventricular fibrillation and were successfully resucitated, but remained comatose. Patients were randomized to standard intensive care support or induced hypothermia. Cooling was achieved by applying ice packs, initiated in the field by paramedics. The primary endpoint was "good outcome" defined as survival to hospital discharge with neurologic function adequate to allow discharge to home or a rehabilitation facility. 43 patients were randomized to the hypothermia group, with $21(43 \%)$ having a good outcome. 33 were randomized to standard support, with only 9 having a good outcome (26\%), (OR=5.25,CI=1.47-18.76, $\mathrm{p}=.011)$. Hypothermia was associated with a lower cardiac index and hyperglycemia. The authors conclude induced hypothermia after ventricular fibrillation cardiac arrest improves outcomes.

\section{Comments}


This study is similar in design albeit smaller than the study performed by the "Hypothermia After Cardiac Arrest Study Group". The results also show a beneficial effect of hypothermia, thus the two studies tend to reinforce each other. What is of interest is that in this study hypothermia resulted in lower cardiac index (with potentially decreased cerbral perfusion) and hyperglycemia both of which may be independently associated with worsened neurologic injury. In spite of this the hypothermia seemed to be protective. In would be interesting to see if other studies show similar results, and if measures to simultaneously improve cardiac index and/or tightly control blood sugar would further increase the cerebral protective effects of hypothermia after cardiac arrest. The specifics of the timing and duration of hypothermia vary somewhat in comparison to the study performed by the "Hypothermia in Cardiac Arrest Study Group". The details of the optimal approach to inducing and maintaining hypothermia post cardiac arrest remain to be worked out in further studies.

\section{Methods}

The authors randomized adult patients who sustained a cardiac arrest with a presenting rhythm of ventricular fibrillation and who remained comatose after successful resucitation. Patients were randomized to prompt cooling to a goal temperature of 33 degrees celsius, which was initiated by paramedics in the field using removal of clothing and application of ice packs, versus standard supportive care. Exclusion criteria included shock $(\mathrm{SBP}<90 \mathrm{mmHg})$, or suspicion of alternative cause of coma such as drug overdose, or cerebrovascular accident. Hypothermia was maintained for 12 hours after which the patient was rewarmed.

\section{References}

1. Bernard SA, Gray TW, Buist MD, Jones BM, Silvester W, Gutteridge G, Smith K.: Treatment of Comatose Survivors of Out of Hospital Cardiac Arrest with Induced Hypothermia. New England Journal of Medicine. 2002, 346: 557-563. 